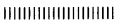

Note

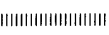

\title{
Effect of Insect Hormone Related Compounds on the Growth of Insect Cells
}

\author{
Hiroto TAMURA, Hirotomi TAKADA, \\ Masahito KITO, Koichi MATSUBARA, \\ Yoshihiko OBARA, Toshio HARA* \\ and Eiichi KUWANO** \\ Department of Agricultural Chemistry, Meijo University, \\ Tempaku-ku, Nagoya 468, Japan \\ *Institute of Genetic Resources, Faculty of Agriculture, \\ and ${ }^{* *}$ Department of Agricultural Chemistry, \\ Kyushu University, Higashi-ku, Fukuoka 812, Japan
}

(Received June 25, 1996 ; Accepted September 17, 1996)

\section{INTRODUCTION}

It is obvious that insect metamorphosis is basically regulated by the balance of the concentration of both juvenile hormone $(\mathrm{JH})$ and ecdysteroid in the hemolymph. Moreover, those low molecular insect hormones are controlled by peptide hormones secreted after recognition of environmental information. ${ }^{1-3)}$ Insect growth regulators have been introduced as insecticides disturbing the regulation of insect hormone system. ${ }^{4)}$ The fruits of insect endocrinology will make it possible to develop new class of insecticides having specific activity to target insects and high selectivity between mammalian and target insects. However, it is not still clear how environmental information is converted to the hormones and how these resultant hormones communicate each other in insect life cycle.

It is already known that insect cell lines play an useful role as tool to examine the influence of insect hormone on the cell growth and morphology.5) To see a mode of action of synthetic insect hormone mimics and regulation mechanism of insect hormone itself, we at first tried to know the effect of them on the growth of IPLB-Sf 21 AEII insect cells. Methoprene as a JH mimic showed cell growth promotion activity but tebufenozide (RH-5992), an ecdysteroid agonist, inhibited cell growth. ${ }^{6)}$ However, no significant response was observed by KK-42, which induces precocious matamorphosis in larvae of the silkworm. ${ }^{7)}$ This paper describes these results in detail.

\section{MATERIALS AND METHODS}

\section{Cell Line and Subcultures}

The insect cell line used was IPLB-Sf 21 AEII (Sf21) established from Spodoptera frugiperda. ${ }^{8}$ Stock-culture of the cells were performed at $25^{\circ} \mathrm{C}$ for 5 days for each generation
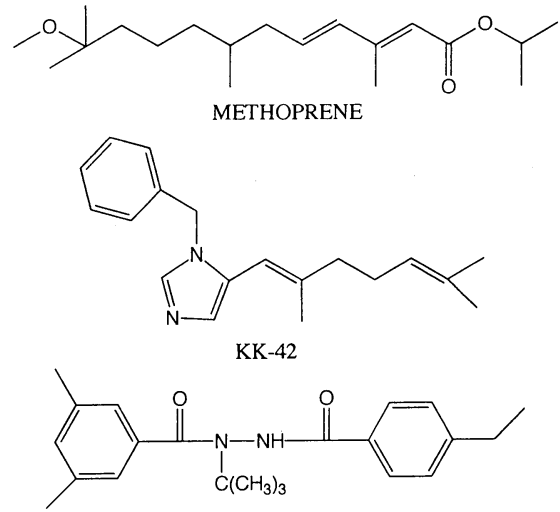

TEBUFENOZIDE

Fig. 1 Structures of insect growth regulators used in this study.

with an initial cell density of $1.0 \times 10^{5}$ cells $/ \mathrm{ml}$ in the IPL-41 medium with $10 \%$ fetal bovine serum (FBS) (Gibco Labs.). Their preculture was done with an initial cell density of $5.0 \times$ $10^{5} \mathrm{cell} / \mathrm{ml}$ at same conditions as stock-culture.

\section{Assay for the Effect of Synthetic Insect Hormone Mimics}

Three synthetic insect growth regulators were examined (Fig. 1). Each compound dissolved in acetone (Wako Co.) was diluted by IPL-41 medium and filtered by sterile membrane filter (Advantec Co.). The final concentration of acetone in test medium was adjusted to below $0.05 \%$. The cells growing at the logarithmic phase (3rd day of pre-culture) were harvested and suspended in the media supplemented with $1 \%$ FBS to a cell density of $1.0 \times 10^{5} \mathrm{cells} / \mathrm{ml}$. To each cell suspension $(0.45 \mathrm{ml})$ on a micro test plate (Falcon 3847$)$ was added $50 \mu 1$ of a test solution mentioned above. The plate was sealed with Falcon film and incubated at $25^{\circ} \mathrm{C}$ for 5 days, and then viable cells determined by trypan blue exclusion, as cell number, were counted with a hemocytometor under an optical microscope (Olympus Ltd.). ${ }^{9}$ The experiment was repeated four times with triplicate per each experiment.

\section{RESULTS AND DISCUSSION}

Insect cell line, Sf 21 established from S. frugiperda, was examined as to its sensitivity to insect growth regulators. When the medium for Sf 21 cells was supplemented with FBS at concentration less than standard level (10\%), growth of the cells was suppressed. In this experiment, therefore, the cells were incubated in the medium supplemented with 1\% FBS and test compound's solution at various concentrations and the effect of FBS-supplementation to the medium was examined. The results of methoprene as a $\mathrm{JH}$ mimic were shown in Table 1. Cell growth was markedly promoted at 
Table 1 Effect of insect growth regulators on the growth of IPLB-Sf21 AEII cells. ${ }^{\text {a) }}$

\begin{tabular}{lccc}
\hline \multirow{2}{*}{$\begin{array}{l}\text { Concentration of } \\
\text { compounds }(M)\end{array}$} & \multicolumn{3}{c}{ Cell number $\left(\times 10^{5}\right.$ cells $\left./ \mathrm{ml}\right)$} \\
\cline { 2 - 4 } & Methoprene & Tebufenozide & KK-42 \\
\hline $10 \%$ FBS & $7.1 \pm 0.35$ & $6.9 \pm 0.85$ & $7.1 \pm 0.60$ \\
$1 \%$ FBS & $5.1 \pm 0.45$ & $5.0 \pm 0.93$ & $5.1 \pm 1.50$ \\
$3.7 \times 10^{-7}$ & $6.0 \pm 0.05$ & $3.3 \pm 0.21$ & $4.3 \pm 0.20$ \\
$3.7 \times 10^{-8}$ & $6.0 \pm 0.35$ & $4.2 \pm 0.16$ & $5.1 \pm 0.05$ \\
$3.7 \times 10^{-9}$ & $6.5 \pm 0.27$ & $4.9 \pm 0.56$ & $5.7 \pm 0.45$ \\
$3.7 \times 10^{-10}$ & $6.9 \pm 0.31$ & $5.5 \pm 0.67$ & $5.6 \pm 0.05$ \\
$3.7 \times 10^{-11}$ & $6.7 \pm 0.35$ & $5.5 \pm 0.62$ & $5.4 \pm 0.25$ \\
$3.7 \times 10^{-12}$ & $6.4 \pm 0.33$ & - b) & - \\
\hline
\end{tabular}

a) Cells were incubated at $25^{\circ} \mathrm{C}$ for 5 days. Ten and 1\% FBS indicated the cell growth in the standard 10\% FBS and $1 \%$ FBS supplemented medium without insect growth regulators, respectively. For the detail, see the text. Average and S. D. values for twelve assays are shown.

b) Not determined.

the optimum concentration of $3.7 \times 10^{-10} \mathrm{M}$ and the cell number at this concentration was as same as one cultured in the standard medium containing 10\% FBS. However a notable response was not observed both at $3.7 \times 10^{-8} \mathrm{M}$ and $3.7 \times 10^{-12}$ M. The growth promotion effects of methoprene suggest that Sf 21 cell line may have a target site like receptor to recognize the chemicals followed by the promotion of cell proliferation. Therefore, to make it clear what is the first interaction between Sf 21 and methoprene, what is the second response to promote the cell growth and what is the molecular base regulation of insect hormone, this cell line may play an useful role as an experimental system since $\mathrm{JH}$ receptor has not been purified yet. ${ }^{10)}$

Whereas tebufenozide acting as an ecdysteroid agonist had a tendency to suppress the proliferation of the cell and the higher the concentration was, the higher the inhibitory effect was (Table 1). Although tebufenozide stimulates the incorporation of ${ }^{14} \mathrm{C}-\mathrm{N}$-acetylglucosamine to integument fragments during short time contact, this incorporation is inhibited with long term incubation $(72 \mathrm{hr})$ with tebufenozide. ${ }^{11)}$ It is interesting that the contact time with tebufenozide switches the response of integument from the stimulation to the inhibition of the incorporation of ${ }^{14} \mathrm{C}-N$-acetylglucosamine. The detail mode of action of tebufenozide, however, still remains questions to solve. As in our assay system the cells were incubated with it through the experiment, this system was similar to long term incubation experiment of insect integument fragments. Moreover, the fact that the growth of Sf 21 cells was impaired significantly corresponds to the results of long term study on insect integument fragments. Although there were no data related to short term effect of tebufenozide on Sf 21 cell line, it seems that the inhibition of tebufenozide is not site specific response of integument but disorder of cell response. Thus, this cell line system is one of the suitable systems to study the mode of action of tebufenozide.
Although KK-42 known as an ecdysteroid biosynthesis inhibitor ${ }^{12)}$ showed somewhat inhibitory activity at high concentration $\left(3.7 \times 10^{-7} \mathrm{M}\right)$ and this tendency was slightly similar to that observed with tebufenozide as shown in Table 1, its effect was not so significant (Table 1). KK-42 makes severe influences to physiological phenomenon of insects by temporarily depressing the ecdysteroid titer in the larval hemolymph to induce precocious metamorphosis. ${ }^{12)}$ In this system, however, KK-42 did not show any significant effect on cell growth. Through the experiments no morphological change due to the three insect growth regulators was seen in this cell line.

It is concluded that hormone mimics, such as methoprene and tebufenozide, may interact with $\mathrm{Sf} 21$ cells but an inhibitor of hormone biosynthesis like $\mathrm{KK}-42$ may not. It is also reasonable that $\mathrm{Sf} 21$ cells will have hormone dependent response sites like receptor and the subsequent response system. Therefore, the effects of insect hormone mimic on Sf 21 cell growth will have to be clarified and the further research will offer the useful information of insect hormone regulatory system.

\section{ACKNOWLEDGMENTS}

The authors wish to thank Mr. Hiroshi Tarui (Institute of Genetic Resources, Faculty of Agriculture, Kyushu University) for his technical assistance.

\section{REFERENCES}

1) A. Kawakami, H. Kataoka, T. Oka, A. Mizoguchi, M. Kimura-Kawakami, T. Adachi, M. Iwami, H. Nagasawa, A. Suzuki \& H. Ishizaki : Science 247, 1333 (1990)

2) T. Kono, H. Nagasawa, A. Isogai, H. Fugo \& A. Suzuki : Insect Biochem. 21, 185 (1991)

3) K. Imai, T. Konno, Y. Nakazawa, T. Komiya, M. Isobe, K. Koga, T. Goto, T. Yaginuma, K. Sasakibara, K. Hasegawa \& O. Yamashita : Proc. Jpn. Acad. 67, 98 (1991)

4) C. M. Williams : Sci. Am. 217, 13 (1967)

5) H. Tamura \& M. Eto: Agric. Biol. Chem. 49, 3247 (1985)

6) A. C-T. Hsu : "Synthesis and Chemistry of Agrochemicals II : ACS Symposium Series 443," ed. by D. R. Baker, J. G. Fenyes \& W. K. Moberg, Am. Chem. Soc., Washington, D.C., p. 478,1991

7) E. Kuwano, R. Takeya \& M. Eto : Agric. Biol. Chem. 49, 483 (1985)

8) J. L. Vaughn, R. H. Goocwin, G. L. Tompkins \& P. McCawley: In Vitro 13, 213 (1977)

9) R. J. Kuchler: "Biochemical Methods in Cell Culture and Virology," Dowden Hutchinson \& Ross, Inc., Stroudsburg, PE, 1977

10) L. M. Riddiford: Adv. Insect Physiol. 24, 213 (1994)

11) Y. Nakagawa, Y. Soya, K. Nakai, N. Oikawa, K. Nishimura, T. Ueno \& T. Fujita : Pestic. Sci. 43, 339 (1995)

12) O. Yamashita, K. Kadono-Okuda, E. Kuwano \& M. Eto : Agric. Biol. Chem. 51, 2295 (1987) 


\section{要 約}

昆虫ホルモン関連化合物が昆虫培羪細胞の増殖に及ぼ す影響

田村廣人, 高田洋富, 鬼頭将仁, 松原晃一 小原嘉彦, 原 敏夫, 桑野栄一 昆虫の内分泌系を取り巻く情報伝達機構の制御系に関する基 礎的な知見を得ることを目的に，昆虫ホルモン関連物質の存在 下, 昆虫培養細胞 IPLB-Sf 21 AEII (Sf21) の増殖や形態がどの ような影響を受けるかを確認した。幼若ホルモンのアゴニスト
であるメソプレンは, 細胞の増殖を促進し, その最適濃度は, $3.7 \times 10^{-10} \mathrm{M}$ であった.一方, 脱皮ホルモンのアゴニストである テブフェノジドは, 細胞の増殖促進効果はなく, 濃度の上昇と ともに細胞の増殖を阻害した。脱皮ホルモンの生合成阻害剂で ある KK-42 は, テブフェノジドと同様な傾向を示したがその効 果は, 顕著でなかった. Sf 21 細胞は, 昆虫ホルモン類似化合物 に対し，異なる反応を示したことにより，この系は，昆虫ホル モンの情報伝達機構を解析する有効な実験系であることが判明 した. 